удк 378.14

Наталія Маланюк

Київський коледж

транспортної інфраструктури

ORCID ID 0000-0002-4321-0900

DOI 10.24139/2312-5993/2020.09/204-213

\title{
ПРОФЕСІЙНА ПІДГОТОВКА МАЙБУТНІХ ФАХІВЦІВ ЗАЛІЗНИЧНОГО ТРАНСПОРТУ: РЕЗУЛЬТАТИ ЕКСПЕРИМЕНТУ
}

у статті подано результати експериментального дослідження щодо ефективності системи професійної підготовки майбутніх фахівців залізничного транспорту в умовах неперервності освіти. Описано формувальноперетворювальний етап експерименту, для кількісної оцінки результатів експерименту та здійснення їх якісного аналізу використано методи математичної статистики в педагогічній науці (t-критерій Стьюдента та $\chi^{2}$-параметричний критерій Пірсона), що дали змогу оцінити достовірність одержаних результатів.

Ключові слова: професійна підготовка, неперервна освіта, майбутні фахівці, залізничний транспорт, експеримент, дослідження, підвищення ефективності, результати.

Постановка проблеми. Система професійної підготовки майбутніх фахівців залізничного транспорту в умовах неперервності повинна зазнавати вдосконалення та модернізації під впливом зовнішніх та внутрішніх чинників: євроінтеграційні процеси, які охопили Україну (Болонська конвенція, мобільність ринку праці), а також стрімкий розвиток науки й техніки, комп'ютеризація та інформатизація всіх сфер діяльності людини тощо. У світлі описаних чинників зростають вимоги до професійної підготовки майбутніх фахівців залізничного транспорту, оскільки транспортна інфраструктура $\epsilon$ міжнародною галуззю. Тому виникає потреба щодо пошуку шляхів підвищення ефективності та вдосконалення системи професійної підготовки майбутніх фахівців залізничного транспорту в умовах неперервності освіти відповідно до запитів суспільства та ринку праці, ураховуючи новітні надбання в галузі освіти, науки й техніки.

Аналіз актуальних досліджень. Окремі аспекти проблеми підготовки майбутніх фахівців залізничного транспорту розглянуто в працях Р. Сущенка, Ю. Терещенка, Т. Шаргун та ін. У дослідженнях Р. Сущенка здійснено пошук шляхів формування управлінської культури в майбутніх залізничників. У працях Т. Шаргун досліджено в історичному ракурсі підготовку фахівців галузі залізничного транспорту у XIX - першій половині XX століття. Фахівець галузі транспортної інфраструктури Ю.Терещенко описує проблеми підготовки фахівців для залізничного транспорту та пропонує шляхи їх вирішення. Проте проблему підготовки майбутніх фахівців в умовах неперервності професійної 
освіти розглянуто не було. Галузь залізничного транспорту займає чільне місце в економіці кожної країни, тому від рівня підготовки майбутніх фахівців залізничного транспорту залежить результативність здійснюваної ними професійної діяльності.

Мета статті: розглянути та проаналізувати результати педагогічного експерименту щодо ефективності системи професійної підготовки майбутніх фахівців залізничного транспорту в системі «коледж-університет».

Методи дослідження: педагогічний експеримент, методи математичної статистики в педагогічній науці (t-критерій Стьюдента та $\chi^{2}$ параметричний критерій Пірсона), узагальнення, систематизація.

Виклад основного матеріалу. Науковим підґрунтям для здійснення експериментального дослідження стали праці таких науковців, як Ю. Бабанський (Бабанський, 1988; Бабанський, 1989), С. Гончаренко (Гончаренко, 2008), Н. Кузьміна (Кузьміна, 1980), С. Сисоєва (Сисоєва, 2009) та інших. В основу дослідно-експериментальної роботи було покладено принципи-рекомендації щодо здійснення педагогічного експерименту в цілому: цілісного дослідження педагогічного явища; об'єктивності; комплексності; ефективності; перманентності (Гончаренко, 2008).

Авторська модель системи професійної підготовки майбутніх фахівців залізничного транспорту в системі неперервної професійної освіти $€$ певним алгоритмом, реалізовуючи який можна здійснювати вдосконалення освітнього процесу в закладах фахової передвищої та вищої освіти. Підґрунтям побудови цієї системи є такі тези:

- поетапність реалізації змін;

- сприяння активності студентів в освітній діяльності;

- формування освітнього середовища, яке буде спряти розвиткові кращих рис кожного студента;

- важлива роль співпраці між викладачами та студентами;

- застосування інновацій в освітньому процесі;

- реалізація ідей особистісно орієнтованого навчання 3 метою сприянню розвитку особистості кожного студента, ураховуючи його індивідуальні особливості, задатки та здібності, та забезпеченню професійного зростання.

Формувально-перетворювальний етап експерименту відбувався протягом 2016-2020 років. Метою цього етапу експерименту була експериментальна перевірка ефективності розробленої системи професійної підготовки майбутніх фахівців залізничного транспорту в системі «коледжуніверситет». Експериментальна робота велася щодо перевірки результа- 
тивності як традиційної, так і авторської системи підготовки майбутніх фахівців залізничного транспорту. Експериментально-дослідна робота була розпочата зі студентами І курсу (спеціальності 273 «Залізничний транспорт» та 275 «Транспортні технології» (на залізничному транспорті)). Тривав експеримент до складання цими ж студентами випускних іспитів у коледжі.

На початку формувально-перетворювального експерименту велося дослідження ефективності системи формування математичної складової професійної компетентності майбутніх фахівців залізничного транспорту. В експерименті брали участь дві групи студентів спеціальності «Транспортні технології» (на залізничному транспорті) та дві групи студентів спеціальності «Залізничний транспорт», кожна група була поділена на дві підгрупи (за результатами вхідного діагностичного тестування 3 математики) з метою досягнення максимальної рівності в знаннях у підгрупах. Освітній процес у першій підгрупі був організований за експериментальною методикою, а в другій - за традиційною. Лекційний матеріал був прочитаний для всіх підгруп однаково. Практичні роботи в експериментальних та контрольних групах містили однаковий обсяг навчального матеріалу, при цьому була збережена логічна структура навчального матеріалу та терміни його опрацювання і здачі.

Початково до експерименту були залучені 127 студентів (63 особи експериментальна група та 64 особи - контрольна група) Київського коледжу транспортної інфраструктури, 37 студентів - експериментальна група та 38 студентів - контрольна група Хмельницького політехнічного коледжу (спеціальності «Автомобільний транспорт»).

Особлива увагу під час проведення експерименту приділялася формуванню мотивації освітньої діяльності, активізації освітнього процесу шляхом упровадження інноваційних педагогічних технологій та формування вмінь і відповідних навичок.

Формувально-перетворювальний експеримент, що полягав у дослідженні ефективності авторської системи професійної підготовки майбутніх фахівців залізничного транспорту, полягав у реалізації таких етапів: початкового та завершального.

Для здійснення дослідно-експериментальної перевірки дієвості системи професійної підготовки майбутніх фахівців залізничного транспорту було розроблено низку навчально-методичних матеріалів:

- індивідуальних завдань для різних видів контролю;

- методичні вказівки до практичних та самостійних робіт; 
- методичні рекомендації щодо використання інноваційних технологій під час вивчення дисциплін математичного циклу;

- навчально-методичний супровід (основи інтегрального та диференціального числення);

- конспекти лекцій тощо.

Для того, щоб кількісно оцінити результати експерименту, а також здійснити їх якісний аналіз, нами використовувалися методи математичної статистики для педагогічної науки, які дали нам змогу оцінити ймовірність одержаних висновків.

На завершальному етапі формувально-перетворювального експерименту було враховано те, що освітній процес у зВО $\epsilon$ багатогранним, складним, компонентним, що передбачає розгляд педагогічної проблеми з різних ракурсів, а також урахування спеціально створених умов (педагогічних умов), реалізація яких сприяє досягненню поставленої мети експерименту. Адже студенти як експериментальних, так і контрольних груп працювали над засвоєнням одного й того самого навчального матеріалу, тривалість часу на опрацювання навчального матеріалу була однаковою, логічна структура викладу навчального матеріалу залишалася непорушною незалежно від системи навчання. Істотно відрізнялися в освітньому процесі експериментальної та контрольної груп методичні підходи до проведення практичних робіт та організації самостійної діяльності студентів, тому припускаємо, що відмінність у результатах освітнього процесу в експериментальній та контрольній групах буде характеризуватися такими якостями:

- щодо знань студентів (глибина, міцність, гнучкість, системність тощо);

- щодо мотивації освітньої та майбутньої професійної діяльності;

- щодо діяльнісних характеристик (інформаційні процеси; уміння працювати над різними типами проєктів; використання нестандартних підходів до виконання освітньої діяльності та інше);

- щодо якостей мислення (системне, логічне, творче, інтегративне тощо).

Упродовж усього часу, що тривав експеримент, ми системно спостерігали за освітнім процесом як в експериментальних, так і в контрольних групах; як під час лекцій чи практичних робіт, так і під час індивідуальних чи колективних консультацій. Систематично був здійснений аналіз освітньої діяльності студентів із метою виявлення таких його показників: стійкість позитивної мотивації до освітньої діяльності; активність 
студентів; результативність методів та методик навчання, які використовували під час експерименту. Для нашого дослідження було важливо з'ясувати:

- який здійснюють вплив спеціально створені умови експерименту на результативність освітнього процесу, у який вони були впроваджені;

- як можна виявити та дослідити явища й процеси, які з'являються під час освітнього процесу;

- які чинники могли би сприяти подальшому вдосконаленню освітнього процесу, реалізуючи його якісну складову.

За результатами експериментальних досліджень сформованості професійної компетентності та готовності до професійної діяльності майбутніх фахівців залізничного транспорту було обчислено деякі інтегровані показники професійної компетентності й готовності до професійної діяльності. Такі показники було пораховано як на початку експерименту, так і в кінці (табл. 1).

Таблиця 1

Рівні сформованості професійної компетентності (математичної складової) майбутніх фахівців залізничного транспорту

\begin{tabular}{|c|c|c|c|c|c|}
\hline \multirow[t]{2}{*}{ Групи } & \multirow[t]{2}{*}{ Рівні } & \multicolumn{2}{|c|}{ Початок експерименту } & \multicolumn{2}{|c|}{ Завершення експерименту } \\
\hline & & $\begin{array}{l}\text { Кількість } \\
\text { студентів }\end{array}$ & $\%$ & $\begin{array}{l}\text { Кількість } \\
\text { студентів }\end{array}$ & $\%$ \\
\hline \multirow{4}{*}{$\begin{array}{l}\text { ЕГ } \\
\text { (100 } \\
\text { студентів) }\end{array}$} & Початковий & 27 & 27 & 12 & 12 \\
\hline & Середній & 56 & 56 & 53 & 53 \\
\hline & Достатній & 14 & 14 & 27 & 27 \\
\hline & Високий & 3 & 3 & 8 & 8 \\
\hline \multirow{4}{*}{$\begin{array}{l}\text { КГ } \\
\text { (102 } \\
\text { студенти) }\end{array}$} & Початковий & 27 & 26,5 & 22 & 21,6 \\
\hline & Середній & 58 & 56,9 & 60 & 58,8 \\
\hline & Достатній & 13 & 12,7 & 15 & 14,7 \\
\hline & Високий & 4 & 3,9 & 5 & 4,9 \\
\hline
\end{tabular}

Аналізуючи дані таблиці 1, можемо засвідчити результативність запропонованої системи професійної підготовки майбутніх фахівців. У студентів експериментальних груп було зафіксовано вищу пізнавальну активність, а також їх знання характеризувалися більшою системністю та здатністю до інтеграції, на відміну від студентів контрольних груп.

Студенти експериментальних груп виявляли вищий рівень когнітивних процесів, їх мисленнєва діяльність характеризувалася чіткістю логічних структур, швидкістю мислення, оригінальністю підходів щодо вирішення навчальних завдань. У більшості студентів експериментальних груп проявлялося стійке ціннісно-мотиваційне утворення, яке сприяло розумінню необхідності успішного виконання освітньої діяльності та її ролі 
для подальшої професійної діяльності. Студенти експериментальних груп проявляли більшу ініціативність під час підготовки проєктів, якісніше виконували домашні (самостійні) завдання.

У студентів контрольної групи, у яких навчання відбувалося за традиційною освітньою системою, знання характеризувалися розрізненістю, поверховістю, відсутністю міжпредметної інтеграції. Студентам складно було виконувати завдання, до яких не було додано шаблону чи алгоритму. Часто в студентів було відсутнє розуміння того, навіщо їм дана освітня дисципліна, а також ії роль для подальшої успішної професійної діяльності. У суттєвої кількості студентів контрольних груп виявлено відсутність стійкої позитивної мотивації щодо освітнього процесу в цілому, а також щодо вивчення окремих навчальних дисциплін. У більшої кількості студентів контрольних груп у порівнянні з експериментальними проявлялася схильність до виконання мінімальної кількості завдань із середньою та низькою якістю виконаної роботи, відсутність бажання саморозвитку та самовдосконалення. Це пов'язано, напевно, з усталеним ще зі школи підходом до навчання, який характеризувався відсутністю зацікавленості до самого процесу здобуття освіти.

Таким чином, результати виконання інтегрованих тестових завдань, а також анкетувань засвідчили зміни в показниках математичної складової професійної компетентності майбутніх фахівців в експериментальних та контрольних групах коледжів. На основі одержаних результатів тестувань та анкетувань студентів експериментальних та контрольних груп можна зробити висновок щодо ефективності запропонованої системи професійного навчання в коледжі. Студенти коледжів, які працювали в експериментальних групах, проявляли бажання до самовдосконалення та саморозвитку, а також прагнення до навчання в університеті з метою поглиблення професійних знань, умінь та навичок.

Динаміку зміни математичної складової професійної компетентності в ЕГ та КГ подано на рис. 1.

Результати експерименту засвідчили, що в експериментальних групах кількість студентів із високим рівнем сформованості математичної складової професійної компетентності зросла на $5 \%$, у той час як у контрольній групі лише на $1 \%$; кількість студентів із достатнім рівнем в ЕГ зросла на $13 \%$, а в КГ - на $2 \%$. У той час зауважимо, що кількість студентів з ЕГ, у яких виявлено середній рівень сформованості математичної складової професійної компетентності зменшилася на 3 \%, а в КГ зросла на 
1,9\%; також в ЕГ зменшилася кількість студентів із початковим рівнем на $15 \%$, а в КГ - на 4,9\%.

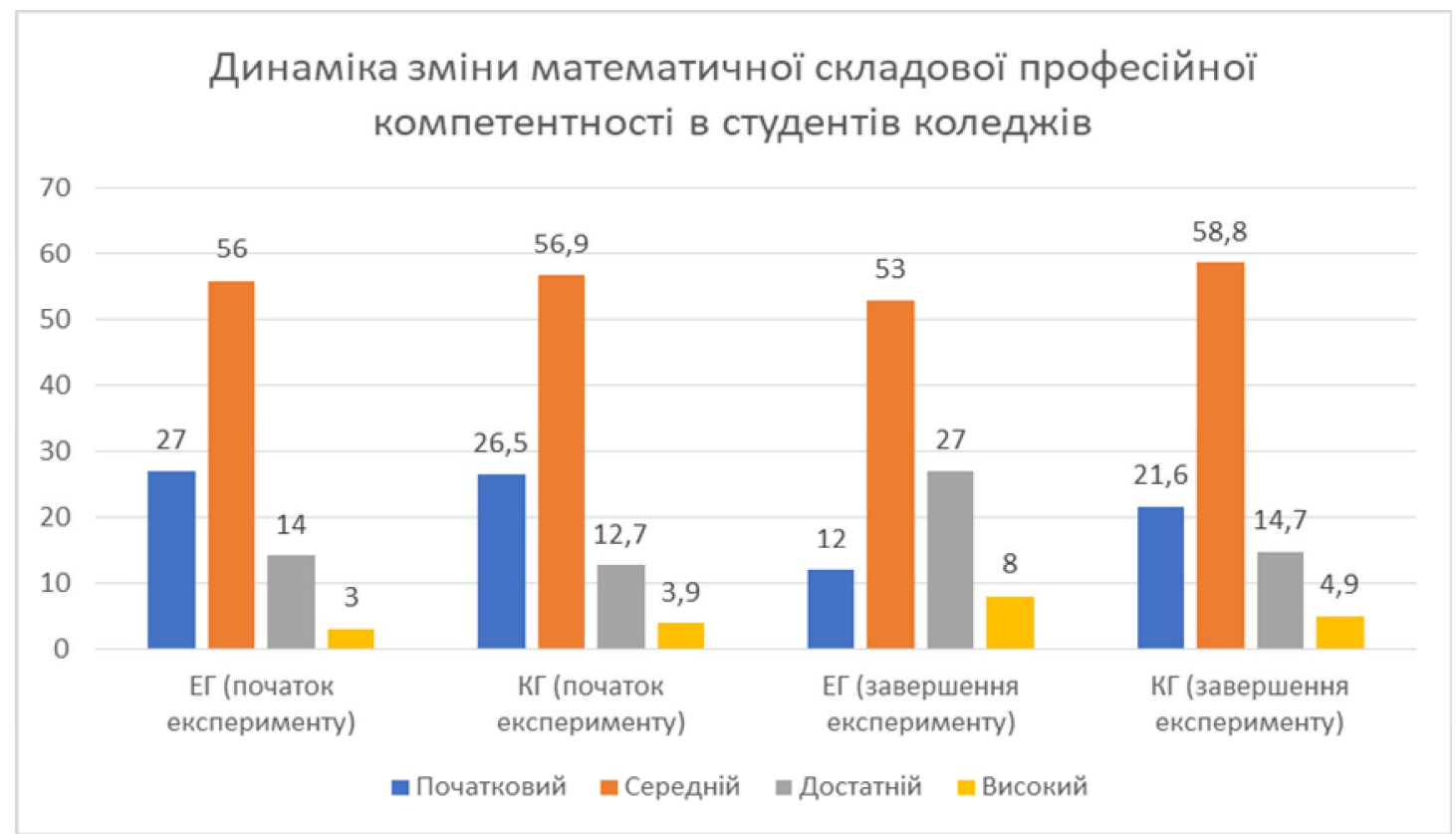

Рис. 1. Динаміка зміни математичної складової професійної компетентності в студентів коледжів на початку експерименту та на завершення експерименту

Зупинимося детальніше на ключових результатах, одержаних у ході проведення експериментального дослідження для компонентів (когнітивного, ціннісно-мотиваційного, операційно-діяльнісного та рефлексивного) готовності до професійної діяльності майбутніх фахівців. Тестові інтегровані завдання проводилися на початку вивчення дисципліни, після кожного з двох модулів, а також після завершення вивчення дисципліни. Результати інтегрованих тестувань подано в табл. 2. Аналіз результатів засвідчив таке:

- підвищення якості знань та вмінь студентів ЕГ, помітну позитивну динаміку;

- формування стійких позитивних ціннісно-мотиваційних орієнтирів щодо вивчення окремих дисциплін, а також щодо освітнього процесу в цілому та подальшої професійної діяльності;

- покращення рівня сформованості професійної компетентності та готовності до професійної діяльності в майбутніх фахівців залізничного та автомобільного транспорту.

Опитування, які були проведені зі студентами ЕГ після завершення експерименту, засвідчило позитивне ставлення учасників експерименту до методик та технологій, які були застосовані під час експерименту в освітньому процесі $(92,8 \%$ усіх опитаних). 
Таблиця 2

\section{Динаміка сформованості готовності до професійної діяльності майбутніх фахівців залізничного транспорту}

\begin{tabular}{|c|c|c|c|c|c|c|c|c|c|}
\hline \multirow[t]{4}{*}{ Групи } & \multirow[t]{4}{*}{ Рівні } & \multicolumn{8}{|c|}{ Кількість студентів } \\
\hline & & \multicolumn{8}{|c|}{ Ціннісно-мотиваційний компонент } \\
\hline & & \multicolumn{2}{|c|}{ I тест } & \multicolumn{2}{|c|}{ II тест } & \multicolumn{2}{|c|}{ III тест } & \multicolumn{2}{|c|}{ IV тест } \\
\hline & & aбc. & $\%$ & абс. & $\%$ & абс. & $\%$ & абс. & $\%$ \\
\hline \multirow{4}{*}{$\begin{array}{l}\text { ЕГ } \\
(100)\end{array}$} & Початковий & 27 & 27 & 21 & 21 & 9 & 9 & 0 & 0 \\
\hline & Середній & 53 & 53 & 55 & 55 & 61 & 61 & 63 & 63 \\
\hline & Достатній & 18 & 18 & 21 & 21 & 25 & 25 & 29 & 29 \\
\hline & Високий & 2 & 2 & 3 & 3 & 5 & 5 & 8 & 8 \\
\hline \multirow{4}{*}{$\begin{array}{l}\text { КГ } \\
(102)\end{array}$} & Початковий & 26 & 25,5 & 25 & 24,5 & 19 & 18,6 & 14 & 13,7 \\
\hline & Середній & 53 & 52 & 53 & 52 & 55 & 53,9 & 60 & 58,8 \\
\hline & Достатній & 22 & 21,5 & 23 & 22,5 & 26 & 25,5 & 25 & 24,5 \\
\hline & Високий & 1 & 1 & 1 & 1 & 2 & 2 & 3 & 3 \\
\hline & & \multicolumn{8}{|c|}{ Когнітивний компонент } \\
\hline \multirow{4}{*}{$\begin{array}{l}\text { ЕГ } \\
(100)\end{array}$} & Початковий & 16 & 16 & 14 & 14 & 10 & 10 & 5 & 5 \\
\hline & Середній & 61 & 61 & 60 & 60 & 58 & 58 & 56 & 56 \\
\hline & Достатній & 18 & 18 & 20 & 20 & 24 & 24 & 29 & 29 \\
\hline & Високий & 5 & 5 & 6 & 6 & 8 & 8 & 10 & 10 \\
\hline \multirow{4}{*}{$\begin{array}{l}\text { КГ } \\
(102)\end{array}$} & Початковий & 15 & 14,7 & 14 & 13,7 & 13 & 12,7 & 10 & 9,8 \\
\hline & Середній & 62 & 60,8 & 62 & 60,8 & 63 & 61,8 & 64 & 62,7 \\
\hline & Достатній & 20 & 19,6 & 21 & 20,6 & 21 & 20,6 & 22 & 21,6 \\
\hline & Високий & 5 & 4,9 & 5 & 4,9 & 5 & 4,9 & 6 & 5,9 \\
\hline & & \multicolumn{8}{|c|}{ Операційно-діяльнісний компонент } \\
\hline \multirow{4}{*}{$\begin{array}{l}\text { ЕГ } \\
(100)\end{array}$} & Початковий & 21 & 21 & 18 & 18 & 15 & 15 & 8 & 8 \\
\hline & Середній & 53 & 53 & 49 & 49 & 45 & 45 & 44 & 44 \\
\hline & Достатній & 22 & 22 & 27 & 27 & 31 & 31 & 36 & 36 \\
\hline & Високий & 4 & 4 & 6 & 6 & 9 & 9 & 12 & 12 \\
\hline \multirow{4}{*}{$\begin{array}{l}\text { КГ } \\
(102)\end{array}$} & Початковий & 22 & 21,6 & 18 & 17,6 & 17 & 16,7 & 12 & 11,8 \\
\hline & Середній & 55 & 53,9 & 57 & 55,9 & 58 & 56,8 & 61 & 59,8 \\
\hline & Достатній & 21 & 20,6 & 23 & 22,5 & 24 & 23,5 & 25 & 24,5 \\
\hline & Високий & 4 & 3,9 & 4 & 4 & 3 & 3 & 4 & 3,9 \\
\hline & & \multicolumn{8}{|c|}{ Рефлексивний компонент } \\
\hline \multirow{4}{*}{$\begin{array}{l}\text { ЕГ } \\
(100)\end{array}$} & Початковий & 14 & 14 & 5 & 5 & 0 & 0 & 0 & 0 \\
\hline & Середній & 36 & 36 & 38 & 38 & 36 & 36 & 25 & 25 \\
\hline & Достатній & 42 & 42 & 45 & 45 & 49 & 49 & 54 & 54 \\
\hline & Високий & 8 & 8 & 12 & 12 & 15 & 15 & 21 & 21 \\
\hline \multirow{4}{*}{$\begin{array}{l}\text { КГ } \\
(102)\end{array}$} & Початковий & 15 & 14,7 & 11 & 10,8 & 7 & 6,8 & 5 & 4,9 \\
\hline & Середній & 37 & 36,3 & 38 & 37,2 & 39 & 38,2 & 40 & 39,2 \\
\hline & Достатній & 43 & 42,2 & 45 & 44,1 & 46 & 45 & 46 & 45 \\
\hline & Високий & 7 & 6,8 & 8 & 7,9 & 10 & 10 & 11 & 10,9 \\
\hline
\end{tabular}

Дані таблиці ілюструють позитивну динаміку зміни всіх досліджуваних компонентів готовності до професійної діяльності майбутніх фахівців залізничного транспорту як в ЕГ, так і в КГ. Проте зміни в ЕГ значно суттєвіші, ніж зміни тих самих показників у КГ. Отримані результати 
підтверджують ефективність запропонованої системи підготовки майбутніх фахівців залізничного транспорту в порівнянні з традиційною системою.

Було сформульовано гіпотези дослідження:

- $\mathrm{H}_{0}$ - емпіричні розподіли студентів у експериментальних та контрольних групах на початку та в кінці експерименту не відрізняються між собою;

- $\mathrm{H}_{1}$ - емпіричні розподіли студентів в експериментальних та контрольних групах на початку та в кінці експерименту відрізняються між собою.

Перевірку гіпотез було здійснено відносно даних на початку та в кінці експерименту за допомогою t-критерію Стьюдента та $\chi^{2}$-параметричного критерію Пірсона. Використовувалися обидва критерії з метою забезпечення комплексності та перманентності одержаних результатів та висновків.

Застосування t-критерію Стьюдента та $\chi^{2}$-параметричного критерію Пірсона засвідчили достовірність отриманих результатів та висновків (95 \%$99 \%$ ) (Новиков, 2007).

Висновки та перспективи подальших наукових розвідок. Таким чином, професійна підготовка майбутніх фахівців залізничного транспорту буде ефективнішою, якщо вона буде базуватися на принципах особистісно орієнтованого навчання із застосуванням інноваційних педагогічних технологій, а також будуть ураховані сучасні досягнення в сфері науки й техніки, узгодженості між ступенями неперервної професійної освіти. Наші подальші дослідження будуть спрямовані на виокремлення й дослідження зв'язків між навчанням на різних ступенях неперервної професійної освіти (фахової передвищої та вищої).

\section{ЛІТЕРАТУРА}

Бабанский, Ю.К. (1989). Проблемы повышения эффрективности педагогических исследований. М.: Педагогика (Babanskii, Yu. K. (1989). Problems of increasing the effectiveness of pedagogical research. M .: Pedagogika).

Введение в научное исследование по педагогике (1988). М.: Просвещение (Introduction to Scientific Research in Pedagogy (1988). M.: Prosveschenie).

Гончаренко, С.У. (2008). Педагогічні дослідження: методологічні поради молодим науковцям. К., Вінниця: ДОВ «Вінниця» (Honcharenko, S. U. (2008). Pedagogical research: methodological advice to young scientists. K., Vinnytsia: Vinnytsia LLC).

Кузьмина, Н.В. (1980). Методы системного педагогического исследования. Л.: лгу (Kuzmina, N. V. (1980). M ethods of systemic pedagogical research. L.: LSU).

Новиков, А. М. (2007). Методология. М.: СИНТЕГ (Novikov, А. М. (2007). M ethodology. $M .:$ SINTEG).

Сисоєва, С. О. (2009). Педагогічний експеримент у наукових дослідженнях неперервної професійної освіти. Луцьк (Sysoieva, S. O. (2009). Pedagogical experiment in scientific research of continuing professional education. Lutsk). 


\section{PEЗЮME}

Маланюк Наталья. Профессиональная подготовка будущих специалистов железнодорожного транспорта: результаты эксперимента.

В статье представлены результаты экспериментального исследования эфреективности системы профрессиональной подготовки будущих специалистов железнодорожного транспорта в условиях непрерывности образования. Описан формировочно-преобразовательный этап эксперимента, для количественной оценки результатов эксперимента и осуществления их анализа использованы методы математической статистики в педагогической науке (t-критерий Стьюдента и $\chi^{2}$-параметрический критерий Пирсона), которые позволили оценить достоверность полученных результатов.

Ключевые слова: профрессиональная подготовка, непрерывное образование, будущие специалисты, железнодорожный транспорт, эксперимент, исследование, повышение эфрфективности, результаты.

\section{SUMMARY}

MalaniukNataliia. Future railway transport specialists: results of the experiment.

The article presents the results of an experimental study on the effectiveness of the system of professional education of future railway transport specialists under conditions of lifelong education.

The author's model of professional education system of future railway transport specialists in the system of lifelong professional education is a certain algorithm, implementing which can improve the educational process in institutions of professional higher and higher education. The research and experimental work was based on the principles-recommendations for the implementation of the pedagogical experiment in general: a holistic study of the pedagogical phenomenon; objectivity; complexity; efficiency; permanence. The basis for the construction of this system are the following theses: gradual implementation of changes; promoting student activity in educational activities; educational environment formation which will direct development of the best features of each student; the important role of cooperation between teachers and students; application of innovations in the educational process; implementation of ideas of personality-centered learning in order to promote the development of the personality of each student, taking into account their individual characteristics, inclinations and abilities, and to ensure professional growth.

According to the results of experimental studies of professional competence formation and readiness for professional activity of future railway transport specialists some integrated indicators of professional competence and readiness for professional activity were calculated. Research hypotheses (zero and alternative) were formulated.

The article describes the molding-transformative stage of the experiment, for quantitative evaluation of experimental results and their qualitative analysis used methods of mathematical statistics in pedagogical science (Student's t-test and Pearson's $\chi^{2}$ parametric test), which allowed to assess the reliability of the results. The obtained results confirm the effectiveness of the proposed system of future railway transport specialists' education in comparison with the traditional system.

Key words professional education, continuing education, future specialists, railway transport, experiment, research, efficiency increase, results. 